\title{
Review
}

Journal of Innate

Immunity
J Innate Immun 2015;7:116-126

DOI: $10.1159 / 000368233$
Received: July 17, 2014

Accepted after revision: September 9, 2014 Published online: November 8, 2014

\section{Myeloid-Derived Suppressor Cells: Paradoxical Roles in Infection and Immunity}

\author{
Jun Dai ${ }^{a}$ Mohamed El Gazzar ${ }^{\mathrm{a}}$ Guang Y. Li ${ }^{\mathrm{a}}$ b Jonathan P. Moorman ${ }^{\mathrm{a}-\mathrm{c}}$ \\ Zhi Q. Yao ${ }^{\mathrm{a}-\mathrm{c}}$ \\ ${ }^{a}$ Center for Inflammation, Infectious Diseases and Immunity, and b Division of Infectious, Inflammatory and Immunological \\ Diseases, Department of Internal Medicine, Quillen College of Medicine, East Tennessee State University, and \\ 'HCV/HIV Program, James H. Quillen VA Medical Center, Johnson City, Tenn., USA
}

\section{Key Words}

Immunity · Infection · Inflammation · Myeloid-derived

suppressor cells

\begin{abstract}
Myeloid-derived suppressor cells (MDSCs) are a heterogeneous population of immature suppressor cells that are generated due to aberrant myelopoiesis under pathological conditions. Although MDSCs have been recognized for more than 20 years under the guise of different monikers, these particular populations of myeloid cells gained more attention recently due to their immunosuppressive properties, which halt host immune responses to growing cancers or overwhelming infections. While MDSCs may contribute to immune homeostasis after infection or tissue injury by limiting excessive inflammatory processes, their expansion may be at the expense of pathogen elimination and thus may lead to disease persistence. Therefore, MDSCs may be either damaging or obliging to the host by attenuating, for example, antitumor or anti-infectious immune responses. In this review, we recapitulate the biological and immunological aspects of MDSCs, including their generation, distribution, trafficking and the factors involved in their activation, expansion, suppressive functions, and interplay between MDSCs and regulatory T cells, with a focus on the perspectives of infection and inflammation.
\end{abstract}

(c) 2014 S. Karger AG, Basel (c) 2014 S. Karger AG, Basel

$1662-811 \mathrm{X} / 14 / 0072-0116 \$ 39.50 / 0$

\section{Introduction}

Myeloid-derived suppressor cells (MDSCs) have been recognized for more than 20 years since their initial description in patients with cancer [1-3]. They have been identified by several monikers, including 'natural suppressor cells', 'immune myeloid cells', 'suppressor macrophages' and, recently, MDSCs $[2,4]$. As opposed to their suppressive functions in chronic inflammation [5], evolving evidence indicates that MDSCs possess the inherent nature of the M1 macrophages seen in acute stages of infection, which express high levels of inducible nitric oxide synthase (iNOS), arginase 1 (ARG1) and reactive oxygen species (ROS), all of which are important mediators of innate immune responses against pathogenic infections [6-10]. However, how these functional mediators can affect aspects of the innate immune response is still an open question.

The immunosuppressive activities of MDSCs have been documented predominantly in cancer patients or tumor-bearing animals and during inflammation or infections, as they have been shown to suppress immune responses against tumors or microbes $[6,7,11,12]$. There has been active debate as to whether MDSCs are beneficial or deleterious to host immunity against intruding pathogens. We now realize that MDSCs may be helpful to the host under certain circumstances, yet harmful in others. In addition to their roles in suppressing host immune responses, their immunosuppressive properties can be

\section{KARGER 125}

E-Mail karger@karger.com

www.karger.com/jin
Prof. Zhi Q. Yao

Division of Infectious, Inflammatory and Immunological Diseases Department of Internal Medicine, Quillen College of Medicine East Tennessee State University, Johnson City, TN 37614 (USA) E-Mail Yao@etsu.edu 


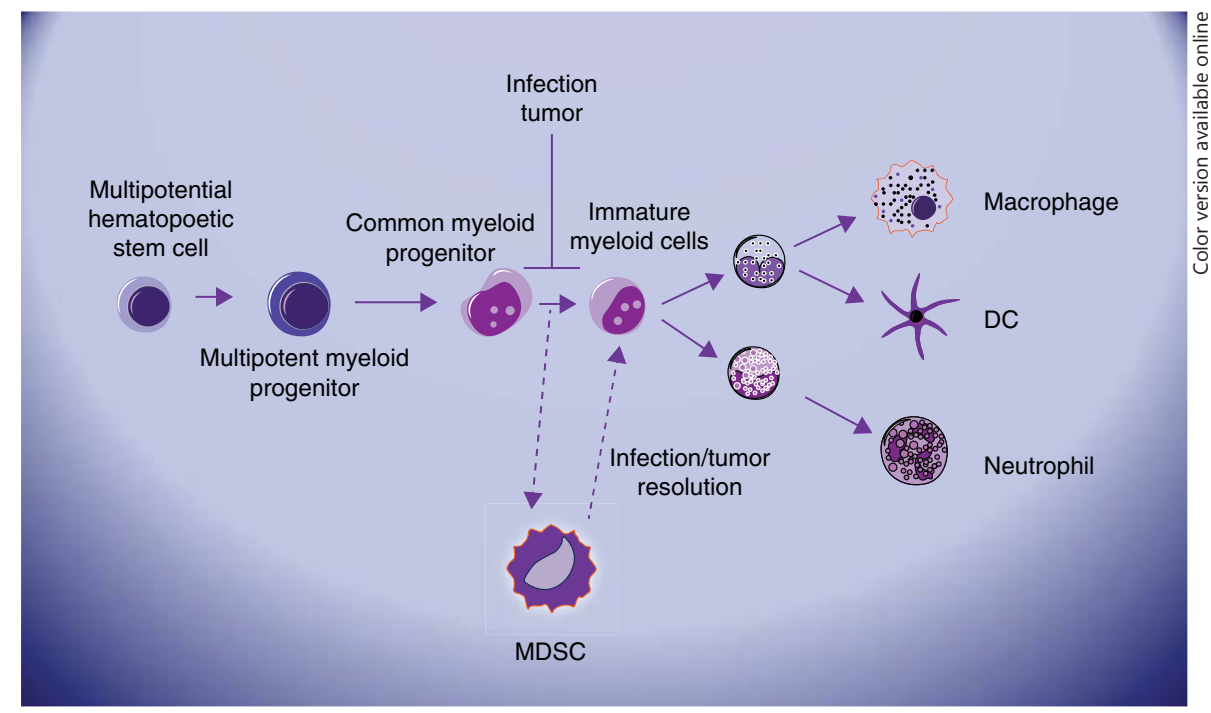

Fig. 1. The genesis of MDSCs. Long-term multipotential hematopoietic stem cells in the bone marrow give rise to short-term hematopoietic stem cells, which further differentiate into multipotent myeloid progenitors and then common myeloid progenitors. These evolve into IMCs, which under steady-state conditions leave the bone marrow as myeloid precursor cells and migrate to peripheral tissues, such as the spleen and lymph nodes, where they dif- ferentiate into macrophages, DCs and granulocytes/neutrophils under the influence of specific tissue factors. Under pathological conditions, such as progressive infection/inflammation or growing tumor burden, these IMCs follow a different differentiation pathway to produce MDSCs with suppressive functions. Notably, resolution of infection or tumor permits MDSC development toward the steady-state myeloid development process. exploited, for example, in suppressing the immune response to a graft transplant. These same immunosuppressive properties may make MDSCs an important component in hindering immune cell homeostasis and in facilitating persistent infections.

MDSCs appear to protect the host from devastating tissue damage during the initial stages of infection by attenuating an overwhelming inflammatory process [13-16]. In the early stages of severe inflammatory conditions such as sepsis, the administration of anti-Gr-1 antibody has been reported to reduce the numbers of MDSCs and to prevent the Th2-polarized immune response and the suppression of $\mathrm{CD}^{+}$and $\mathrm{CD} 8^{+} \mathrm{T}$ cells during severe sepsis, suggesting that MDSCs may play an immunosuppressive role during sepsis [15]. However, this approach did not improve outcome, perhaps attributed to the nonspecificity of the antiGr-1 that also depletes mature neutrophils [15]. Another study has shown that depletion of MDSCs during early severe sepsis reduced survival, suggesting that MDSCs play an immunoprotective rather an immunosuppressive role during sepsis [17]. It should be noted that the inflammatory response to sepsis is a dynamic process, as it shifts from an early severe hyperinflammatory state to a late immunosuppressive state. Thus, data regarding depletion of MDSCs in sepsis and whether they play a protective or immunosuppressive role should be interpreted with caution. We have recently shown that, in the course of murine sepsis, MDSCs can enhance (proinflammatory) or suppress (immunosuppressive) severe inflammation of early sepsis, depending on the context in which they expand [13]. We have shown that MDSCs derived from early septic mice were proinflammatory, whereas MDSCs derived from late septic mice were immunosuppressive, and they improved survival only during early septic hyperinflammation [13]. This led us to conclude that, at least in sepsis, MDSC phenotype and activity depend largely on the environment in which they expand and function.

\section{MDSC Origin and Distribution}

MDSCs primarily include immature myeloid cells (IMCs), in addition to some mature neutrophils and macrophages, with half-lives ranging from hours to days (fig. 1). Numbers of functionally mature myeloid cells must be maintained by a steady-state asymmetrical myelopoiesis. Long-term hematopoietic stem cells in the bone marrow give rise to short-term hematopoietic stem cells, which further differentiate into multipotent myeloid progenitors and then common myeloid progeni- 
tors, which evolve into erythroid progenitors and IMCs, respectively. Under steady-state conditions, IMCs leave the bone marrow as myeloid precursor cells and migrate to peripheral tissues, such as the spleen, where they differentiate into macrophages, dendritic cells (DCs) and granulocytes or neutrophils under the influence of specific tissue factors [15]. Under certain pathological conditions, such as progressive infection/inflammation or a growing tumor burden, these IMCs follow a different differentiation pathway to produce MDSCs $[6,7]$.

MDSCs are the intermediates of the normal myeloid development and differentiation stages. However, immunosuppressive MDSCs do not expand under normal conditions; these myeloid intermediates or IMCs are reprogrammed and acquire their immunosuppressive properties when they expand in response to a growing tumor or infection/inflammation to become functional, immunosuppressive MDSCs. Under normal conditions, IMCs expressing the $\mathrm{Gr}-1^{+} \mathrm{CD} 11 \mathrm{~b}^{+}$phenotypic marker are usually maintained at a relatively low level in murine bone marrow (20-30\% of overall myeloid cells), peripheral blood (2-4\%), spleen $(2-4 \%)$, pancreas $(1-2 \%)$, liver $(2-5 \%)$ and lymph nodes $(<1 \%)[17,18]$. In peripheral blood of normal mice, the ratio of $\mathrm{Gr}-1^{+} \mathrm{CD} 11 \mathrm{~b}^{+}$IMCs to T cells is $1: 5$, whereas under stress conditions, this ratio is $2: 1$, similar to the ratio in the spleen of septic mice. In septic mouse bone marrow, the ratio can reach up to 16:1 [19-21]. Functionally, Gr $-1^{+} \mathrm{CD} 11 \mathrm{~b}^{+}$IMCs from normal hosts are not immunosuppressive. The varying numbers of MDSCs required to elicit immunosuppressive effects in different in vitro models may explain some of the discrepancies regarding MDSC studies [22]. In humans, there are no details regarding the distribution of IMCs in various tissues, and in healthy subjects IMCs with analogous MDSC phenotypes $\left(\mathrm{Gr}-1^{+} \mathrm{CD} 11 \mathrm{~b}^{+}\right)$do not exert immunosuppressive capability [23-27]. Thus, MDSCs are differentiated from normal IMCs, and they only expand and become immunosuppressive via aberrant myelopoiesis; this generally occurs under certain pathological conditions, such as progressive infection/inflammation or a growing tumor burden.

\section{Aberrant Myelopoiesis and MDSC Expansion}

Of note, dysregulated myelopoiesis appears to be a prerequisite for MDSC expansion and is mediated by both myeloid expansion and activation factors $[7,22]$. These two differential factors are normally present at inflammatory sites and are derived from products of dying (apoptotic) cells or mediators, such as granulocyte/macrophage- colony stimulating factor (GM-CSF) and IFN- $\gamma$, secreted by immune cells. However, neither growth factor alone nor one-sided stimulating factors can trigger myelopoiesis [22]. Administration of high doses of bacterial lipopolysaccharide to mice has been shown to prime transient and modest expansion of MDSCs [5], whereas ex vivo treatment with GM-CSF has been reported to induce MDSC generation from mouse bone marrow in a dose-dependent manner $[28,29]$. In these experimental conditions, however, one cannot exclude the potential contamination with other growth factors, because GM-CSF or lipopolysaccharide alone cannot activate colony proliferation.

Without persistent stimulation, it is difficult to maintain a steady-state expansion of MDSCs. Cultures of tumor-derived MDSCs in the absence of tumor-derived stimuli, or transfer of MDSCs into tumor-free recipients, give rise to mature functional myeloid cells $[7,30,31]$. This is supported by the observation that a drop in the MDSC population occurs after experiencing abscess resolution, primary tumor resection and antiretroviral therapy in HIV patients [11, 32]. Notably, overdosage of GM-CSF as an adjuvant for vaccination or treatment triggers counterregulatory suppressive mechanisms that may conversely dampen its effectiveness due to the possible expansion of MDSCs [33, 34]. Under normal conditions, the body generates physiologically necessary IMCs, which bear MDSCanalogous phenotypes following myelopoiesis to sustain homeostasis. Whether extramedullary myelopoiesis exists in the spleen, liver or lymph nodes under normal conditions remains unknown, but this is highly likely during severe infections, especially in animal disease models [5].

Inflammation leads to increased mobilization of mature myeloid cells, which create niche spaces in the bone marrow reservoir, and excessive production of inflammatory mediators act in concert to skew them from differentiation into mature myeloid cells toward MDSC expansion. A partial interruption or arrest of IMC differentiation into mature myeloid cells leads to the accumulation of MDSCs following their exclusive pathway, which also partially explains why macrophages and DCs do not expand during the generation of MDSCs in late/chronic inflammation $[35,36]$. In the early stages of infection, MDSCs appear to serve as part of the innate immune defense mechanism, and their frequency declines due to the mobilization of the myeloid progenitors to replace the consumed mature myeloid cells. With persistent infection during polymicrobial sepsis, MDSCs expressing CD31 surface antigen, a marker that exists on more IMCs [37], expand in the bone marrow and exponentially increase to nearly 70 -fold compared to controls (i.e. $37-40 \%$ CD $31^{+}$ 


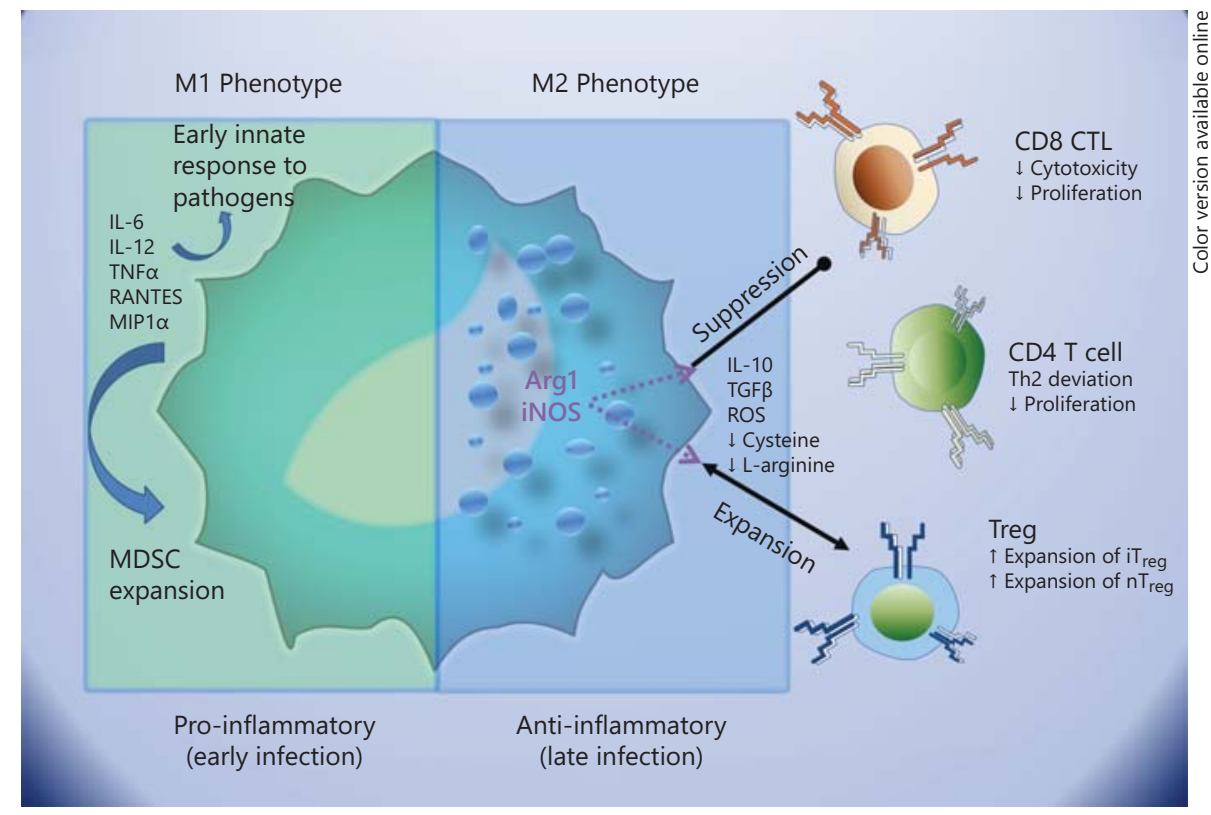

Fig. 2. Paradoxical roles for MDSCs in early and late phases of infection. Early infection is characterized by the emergence of MDSCs which appear to be involved in innate host responses to infectious pathogens, with expression of proinflammatory mediators and cytokines and the general appearance of a more M1-like phenotype. These cytokines include IL-6, IL-12, and TNFa, amongst others, and several of these factors may contribute to further MDSC expansion. Chronic or late infection is characterized

cells of total $\mathrm{Gr}-1^{+} \mathrm{CD} 11 \mathrm{~b}^{+} \mathrm{MDSC}$ on day 3 to nearly $80 \%$ on day 12 after sepsis onset in mice) [37]. In line with this observation, in late septic mice, Gr- $1^{+} \mathrm{CD} 11 \mathrm{~b}^{+} \mathrm{MDSC}$ represented $40 \%$ of the myeloid cells in the spleen, $90 \%$ in the bone marrow and $3-4 \%$ in the lymph nodes (normally, $2-4 \%$ in spleen, $20-30 \%$ in the bone marrow and $<1 \%$ in lymph nodes in naive mice) $[5,13]$.

In addition to the massive increase in the immature $\mathrm{CD} 31^{+}$MDSC subset during sepsis, there is a parallel loss of their ability to differentiate into mature myeloid cells. In a study by Brudecki et al. [13], approximately 38 and $21 \%$ of total Gr- $1^{+} \mathrm{CD} 11 \mathrm{~b}^{+}$MDSCs from day-3 (early) septic mice differentiated into macrophages and DCs, respectively, compared with only 17 and $9 \%$ differentiation when these cells were derived from day-12 (late) septic mice. Interestingly, $\mathrm{CD} 31^{+} \mathrm{Gr}-1^{+} \mathrm{CD} 11 \mathrm{~b}^{+} \mathrm{MDSC}$ from both early and late septic mice exhibited similarly low levels of the differentiation potential $\left(<4 \%\right.$ of CD $31^{+}$MDSCs differentiated into mature myeloid cells).

This phenotypic shift and loss of the differentiation potential of MDCSs due to inflammation persistence was also accompanied by a shift from a proinflammatory to a by the emergence of an M2-like phenotype, with blast-like nuclei and the expression of significant ARG1 and iNOS as well as cytokines such as IL-10 and TGF- $\beta$. The milieu generated contributes to an immunosuppressive/anti-inflammatory environment that includes blunted CD4 and CD8 T cell responses and expansion of both natural $\left(\mathrm{nT}_{\text {reg }}\right)$ and induced $\mathrm{T}_{\text {reg }}\left(\mathrm{iT}_{\text {reg }}\right)$ cells. MIP1 $\alpha=$ Macrophage-inflammatory protein $1 \alpha$.

late anti-inflammatory cytokine profile, characterized by early production of TNFa, IL- 6 and IL-12, and late production of TGF- $\beta$ and IL-10 secretion, and with the disappearance of ring-shaped and blast-like nuclei of MDSCs (fig. 2) [15]. These shifts from the M1- to the M2like macrophage functional phenotype underpin a postinflammatory immunosuppressive state, which also closely correlates with the expansion and phenotypic shift of MDSCs observed in HIV and HCV persistent infections $[13,14,16,38-40]$. Correspondingly, an increased expression of anti-inflammatory genes encoding inhibitory signaling molecules and suppressive cytokines as well as a decreased expression of proinflammatory genes encoding proteins associated with immune tolerance was observed in these studies [41-44].

\section{MDSC Subsets and Phenotypes}

MDSCs are not a defined subset but a heterogeneous population. Their morphology and function differ in different tissues and under different inflammatory condi- 
Table 1. Cell surface phenotypic markers for MDSCs

\begin{tabular}{|c|c|c|c|c|}
\hline \multirow[t]{2}{*}{ Phenotype } & \multicolumn{2}{|l|}{ Human } & \multicolumn{2}{|l|}{ Mouse } \\
\hline & M-MDSCs & G-MDSCs & M-MDSCs & G-DSCs \\
\hline CD11b (Mac-1) & + & + & + & + \\
\hline Gr-1 & $\mathrm{N} / \mathrm{U}$ & $\mathrm{N} / \mathrm{U}$ & $\begin{array}{l}\text { int/low } \\
\text { (dim) }\end{array}$ & $\begin{array}{l}\text { high } \\
\text { (bright) }\end{array}$ \\
\hline Ly6G & $\mathrm{N} / \mathrm{U}$ & $\mathrm{N} / \mathrm{U}$ & - & + \\
\hline Ly6C & $\mathrm{N} / \mathrm{U}$ & N/U & + & - \\
\hline MHC-II (HLA-DR) & low/- & low/- & $\mathrm{N} / \mathrm{U}$ & $\mathrm{N} / \mathrm{U}$ \\
\hline CD14 & + & - & $\mathrm{N} / \mathrm{U}$ & $\mathrm{N} / \mathrm{U}$ \\
\hline CD15 & - & + & $\mathrm{N} / \mathrm{U}$ & $\mathrm{N} / \mathrm{U}$ \\
\hline $\mathrm{CD} 16(\mathrm{Fc} \gamma \mathrm{R})$ & high & int & + & + \\
\hline CD115 (M-CSF1R) & $\mathrm{N} / \mathrm{U}$ & $\mathrm{N} / \mathrm{U}$ & + & $+/-$ \\
\hline $\mathrm{F} 4 / 80$ & $\mathrm{~N} / \mathrm{U}$ & $\mathrm{N} / \mathrm{U}$ & + & - \\
\hline CD31 (PECAM1) & $\mathrm{N} / \mathrm{U}$ & $\mathrm{N} / \mathrm{U}$ & + & - \\
\hline Lin & - & - & $\mathrm{N} / \mathrm{U}$ & $\mathrm{N} / \mathrm{U}$ \\
\hline CD120b & $\mathrm{N} / \mathrm{U}$ & $\mathrm{N} / \mathrm{U}$ & low & low \\
\hline CD125 & + & + & - & - \\
\hline CD124 (IL-4aR) & + & + & + & + \\
\hline CX3 (CR1) & $\mathrm{N} / \mathrm{U}$ & $\mathrm{N} / \mathrm{U}$ & low & high \\
\hline CD33 & high & int & $\mathrm{N} / \mathrm{U}$ & $\mathrm{N} / \mathrm{U}$ \\
\hline CD32 & $\mathrm{N} / \mathrm{U}$ & $\mathrm{N} / \mathrm{U}$ & + & + \\
\hline VEGFR1 & $+1-$ & + & $\mathrm{N} / \mathrm{U}$ & $\mathrm{N} / \mathrm{U}$ \\
\hline CD49d & $\mathrm{N} / \mathrm{U}$ & $\mathrm{N} / \mathrm{U}$ & + & - \\
\hline CD68 & $\mathrm{N} / \mathrm{U}$ & $\mathrm{N} / \mathrm{U}$ & - & + \\
\hline CD40 & $\mathrm{N} / \mathrm{U}$ & $\mathrm{N} / \mathrm{U}$ & + & + \\
\hline CD80 & $\mathrm{N} / \mathrm{U}$ & $\mathrm{N} / \mathrm{U}$ & + & + \\
\hline CD83 & - & - & $\mathrm{N} / \mathrm{U}$ & $\mathrm{N} / \mathrm{U}$ \\
\hline CD66b & - & high & $\mathrm{N} / \mathrm{U}$ & $\mathrm{N} / \mathrm{U}$ \\
\hline MHC I & $\mathrm{N} / \mathrm{U}$ & $\mathrm{N} / \mathrm{U}$ & int & int \\
\hline CD54 (ICAM-1) & $\mathrm{N} / \mathrm{U}$ & $\mathrm{N} / \mathrm{U}$ & high & low \\
\hline CD1d & $\mathrm{N} / \mathrm{U}$ & $\mathrm{N} / \mathrm{U}$ & + & - \\
\hline CCR2 & $\mathrm{N} / \mathrm{U}$ & $\mathrm{N} / \mathrm{U}$ & + & - \\
\hline
\end{tabular}

$\mathrm{N} / \mathrm{U}=$ None or unidentified.

tions. Even within the same inflammatory process, they functionally and phenotypically vary over time and usually share the phenotypic spectrum of mature myeloid cells, such as $\mathrm{CD} 11 \mathrm{c}^{+}$(DC) and $\mathrm{F}^{+} / 80^{+}$(macrophage) [7]. For this reason, MDSCs are more accurately identified by their immunosuppressive functions rather than cell surface markers. In mice, MDSCs are defined as IMCs that co-express the Gr- $1^{+}$and $\mathrm{CD} 11 \mathrm{~b}^{+}$markers, which are also associated with other surface markers at various stages of myeloid cell maturation (table 1). This MDSC population can be further dissected into two subsets based on the expression of the Gr-1 antigen:

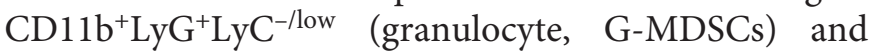

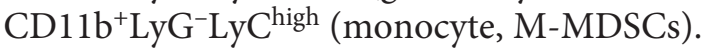

Unlike mice, human MDSCs do not express GR1 antigen, and thus MDSCs are basically defined as two sub- sets: G-MDSCs and M-MDSCs. The G-MDSC phenotype is identified as $\mathrm{Lin}^{-} \mathrm{CD} 11 \mathrm{~b}^{+} \mathrm{CD} 33^{+} \mathrm{HLA}^{-\mathrm{DR}^{-}}$or $\mathrm{CD} 33^{+}$

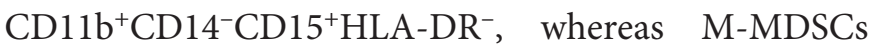
correspond to $\mathrm{CD}_{3} 3^{+} \mathrm{CD} 11 \mathrm{~b}^{+} \mathrm{CD} 14^{+} \mathrm{HLA}^{-} \mathrm{DR}^{-/ \text {low }}[45-$ 52] or $\mathrm{CD} 14^{+} \mathrm{HLA}-\mathrm{DR}^{-/ \text {low }}[49,53]$. G-MDSCs comprise the dominant percentage (70-80\%) of the total MDSC population in tumor-bearing mice or cancer patients, with multilobed nuclei and high side scatter when assessed by flow cytometry [24, 54-56]. In contrast, MMDSCs represent about 20-30\% of the total MDSC population with ring-shaped nuclei and low side scatter. Tumor-associated production of granulocyte CSF in mice might account for the accumulation of G-MDSCs [57].

Investigations in tumor-bearing mice revealed that the two distinctive subsets of MDSCs exert the same level of immunosuppressive effects on $\mathrm{CD}^{+} \mathrm{T}$ effector cells through specific cell-to-cell contact and on $\mathrm{CD}^{+}{ }^{+} \mathrm{T}$ cells via nonspecific humoral immune mechanisms, despite the fact that M-MDSCs have been suggested to be more suppressive than G-MDSCs at the per cell level [23, 55, $58,59]$. G-MDSCs express higher levels of ROS, whereas M-MDSCs produce more iNOS, and both cell subsets express a modest level of ARG1. During bacterial infection or autoimmune encephalomyelitis, for example, these two distinct subsets have been shown to play different immunomodulatory roles $[60,61]$. In persistent infections, G-MDSC and M-MDSC numbers are decreased, with emergence of more immature (blast-like) $\mathrm{CD} 31^{+}$myeloid cells. In tumor settings, G-MDSCs lose the myeloid differentiation potential, but M-MDSCs retain the potential for further maturation [7]. Although these two subsets functionally and/or phenotypically overlap, it is unclear if they can switch into the other phenotype. Whether specific subpopulations predominate and whether their corresponding functions change with the severity of infection or tumor progression needs further investigation.

\section{MDSC Trafficking and Mobilization}

The phenotypic and functional heterogeneity of MDSCs stems, in large part, from the fact that they have been studied in different experimental models, and from the heterogeneity of MDSCs in different tissues and even under similar conditions. Recent studies linked MDSCs to sepsis progression [15]. Makarenkova et al. [62] reported significant increases in the numbers of Gr $-1^{+} \mathrm{CD} 11 \mathrm{~b}^{+}$MDSCs derived from a rapid influx into the spleen 12-24 h after a traumatic injury, with cells expressing more MHC II, less MHC I as well as less of the 
immature myeloid marker CD31. In contrast, Delano et al. [5] observed a transient decline in $\mathrm{Gr}-1^{+} \mathrm{CD} 11 \mathrm{~b}^{+} \mathrm{MD}$ SCs in the spleen during the first $24 \mathrm{~h}$ after sepsis onset but a massive expansion 3-5 days after sepsis. These cells produced copious amounts of the immunosuppressive cytokine IL-10 and were mostly CD $31^{+}[15]$. These data support the hypothesis that IMCs in the bone marrow are recruited to sites of inflammation to replace damaged or exhausted cells, and then become trapped in the local microenvironment where they acquire their immunosuppressive properties from various inflammatory signals. Human subjects with sepsis exhibit increases in the numbers of neutrophils with an immature phenotype due to delayed apoptosis $[63,64]$. Normal neutrophils undergo apoptosis within $24 \mathrm{~h}$ after their release from the bone marrow. Aberrant, septic neutrophils produce small amounts of ROS and show impaired bactericidal activity and loss of chemotactic activity $[65,66]$.

We hypothesize that, with mild or transient endogenous and exogenous insults (scenario 1), such as minimal-to-modest pathogen load, benign neoplasms, trauma or vaccination, IMCs can be recruited transiently at discrete numbers. In this scenario, more mature myeloid cells rather than IMCs are observed, which are more likely to differentiate into mature myeloid cells with less immunosuppressive activities when compared to those cells that arise under severe insults, i.e. MDSCs [19]. An early decline in mature myeloid cells is due to host defense sacrifice or trafficking of IMCs from the bone marrow and their differentiation into MDSCs $[6,7,20]$. We can consider this pathway as a natural host defense response in common, self-limited diseases. In the setting of uncontrolled systemic insults (scenario 2), such as an overwhelming septic infection or a growing tumor burden, inflammatory mediators or immunosuppressive factors derived from infection or metastatic tumor, respectively, can shift myelopoiesis toward accumulation of MDSCs and yet thwart myeloid differentiation $[6,7,15]$. This would lead to an increase in immature phenotype CD $31^{+}$ cells with strengthened immunosuppressive competence [41] along with diminished terminal differentiation potentials and M2 or Th2 polarization - thus dampening circulating proinflammatory cytokines and bactericidal activity $[5,13,14]$. These two scenarios have similarities at the onset (within the first few hours) of the infectious insult in that there is a transient decrease in $\mathrm{Gr}-1^{+} \mathrm{CD} 11 \mathrm{~b}^{+}$ IMCs due to differentiation into mature myeloid cells, which are then mobilized by invading pathogens.

Improving survival via reducing inflammation-induced multiorgan dysfunction comes at the expense of pathogen elimination and the incurrence of secondary insults [13]. An appropriate example for demonstrating suppressive immune responses comparable to MDSC properties is that of tumor-associated macrophages, which directly arise from MDSCs that have migrated to tumor sites, attenuating host antitumor immunity by producing mediators such as ARG1 or iNOS [7, 10, 67, 68]. Whether chronic infections, such as HIV or HCV, promote the expansion of infection-associated myeloid cells like tumor-associated macrophages remains unknown, but we believe that chronic infection may share similar evasion mechanisms as those operating in cancers. Although several factors have been identified that drive MDSC expansion and terminate normal myeloid cell differentiation, including GM-CSF, VEGF, COX-2, IL-10, TGF- $\beta$ and some S100A proteins $[6,7,15]$, it remains unclear how MDSCs traffic to pathologic sites. The answer to this question is further complicated by the lack of specific markers for human MDSCs and the fast-filtering blood compartment [68].

\section{MDSCs in Infection and Tumor}

Generally, most tumors derive from endogenous mutation- or chronic inflammation-induced cell transformation, whereas acute infection is an exogenous pathogen invasion, and these distinct etiologies are likely to determine the diverse immune mechanisms that MDSCs deploy to respond to the respective threat. MDSCs subvert both innate and adaptive immune surveillance and prevent the host immune system from eliminating newly transformed or infected cells [69]. MDSC depletion in a tumor-bearing animal model resulted in tumor recession by altering the inflammatory responses, thus allowing for the restoration of antitumor immune responses due to the elimination of immunosuppressive mediators produced by MDSCs and their subsequent effects on T cells [70]. By contrast, depletion of MDSCs increased host mortality in sepsis due to the loss of the intrinsic ability to inhibit early, unremitting proinflammatory cascades, especially in the early stage of sepsis in which proinflammatory cytokines induce an inflammatory storm [17].

It is possible that the net benefit of limiting expansion of MDSCs contributes to the establishment of antitumor immunity, as their expansion and activities negatively affect the host secondary defense system by inhibiting antigen-presenting DC and antigen-specific $\mathrm{CD} 8^{+} \mathrm{T}$ cells to cell-mediated antitumor immunity $[6,7]$. In the context of infection, MDSC depletion increases the risk of suscep- 
Table 2. Functional protein and cytokine expression in MDSCs

\begin{tabular}{|c|c|c|c|c|}
\hline \multirow{2}{*}{$\begin{array}{l}\text { Protein and } \\
\text { cytokine } \\
\text { expression }\end{array}$} & \multicolumn{2}{|l|}{ Human } & \multicolumn{2}{|l|}{ Mouse } \\
\hline & M-MDSCs & G-MDSCs & M-MDSCs & G-MDSCs \\
\hline S100A8 & $\mathrm{N} / \mathrm{U}$ & $\mathrm{N} / \mathrm{U}$ & + & + \\
\hline S100A9 & + & + & + & + \\
\hline ARG1 & + & + & + & + \\
\hline ROS & low & high & low & high \\
\hline iNOS & high & low & high & low \\
\hline IL-10 & + & - & + & + \\
\hline IL-13 & + & - & - & - \\
\hline TGF- $\beta$ & + & - & - & - \\
\hline SSC & low & high & low & high \\
\hline
\end{tabular}

$\mathrm{N} / \mathrm{U}=$ None or unidentified.

tibility to primary or secondary infection as well as the risk of overwhelming inflammation $[13,15,71,72]$. Severe infections such as sepsis are typically defined by the production of early proinflammatory cytokines such as TNF $\alpha$ and IL-6, and late anti-inflammatory cytokines such as IL-10 and TGF- $\beta$ (table 2) [13]. Initial proinflammatory cytokines increase pathogen clearance but decrease survival due to incurring drastic inflammatory responses, resulting in multiple organ failure, whereas late anti-inflammation incurs overall immunosuppression and susceptibility to secondary infection $[13,72]$. The question remains whether one should manipulate sepsis pathophysiology by employing different approaches against both the early hyperinflammatory response and the late immunosuppression based on a predicted time point. One could envision a selective approach in treating sepsis may require the use of anti-inflammatory therapy to attenuate and resolve early sepsis hyperinflammation in order to prevent multiple organ injury, while employing immunostimulatory therapy to resolve late sepsis immunosuppression once it has developed.

It is more complex in the clinical scenario, as most clinicians believe that immunosuppression, rather than intractable, low-grade inflammation, is the predominant driving force for morbidity and mortality in late-septic patients [73]. Regulation of immune activation by MDSCs based on a patient's differential immune status and disease stage is apparently important but also challenging. During severe inflammation, the host immune system may prevent self-damage from proinflammatory reactions that are induced by an overwhelming pathogen burden, but this comes at the expense of failing to eliminate infection, leading to disease persistence. In compar- ison, chronic infections share more common features with tumor progression, characterized by immunosuppression in the advanced stages.

\section{MDSC-Suppressive Mechanisms and Interactions with Regulatory T Cells}

Functionally, MDSCs generated in the setting of chronic infections or chronic inflammation have more suppressive activities than MDSCs that arise under acute conditions, such as severe systemic inflammation during early murine sepsis [13]. It has been suggested that the accumulation of MDSCs due to accelerated myelopoiesis during chronic inflammation, such as in late sepsis, is not simply an expansion in their numbers or expression of phenotypes, but rather an enhanced suppressive function gained under pathological conditions. Gr- $1^{+}$MDSCs from tumor-bearing mice injected into healthy mice rapidly lose their immunosuppressive phenotypes [15].

Using a murine model of induced prostate inflammation, Haverkamp et al. [74] reported that MDSC-suppressive functions were only limited to the site of inflammation, suggesting that the robustness of the inflammatory response determines the gradual-grade spreading of immune privilege. In addition, it has been suggested that MDSCs alone or synergistically with $\mathrm{T}$ regulatory $\left(\mathrm{T}_{\text {reg }}\right)$ cells can contribute to the progression or latency of HIV infection, and this may explain the lack of efficacy of some immune-based treatments and vaccinations [11, 75-80]. As summarized in the review by Gabrilovich et al. [52], MDSCs can suppress $T$ cell activation and function by several mechanisms, including (A) deprivation of essential nutrients like L-arginine, L-cysteine and tryptophan from the $\mathrm{T}$ cell environment: (B) nitrosylation of $\mathrm{T}$ cell receptors by oxidative stress; (C) interference with lymphocyte trafficking and viability via inhibitory molecules or receptors, and (D) amplification of immune suppression by inducing $\mathrm{T}_{\text {reg }}$ proliferation and differentiation.

The role of $\mathrm{T}_{\text {reg }}$ cells in transplantation and autoimmune diseases has been well studied, where MDSCs have been shown to induce immune tolerance and reduce transplant rejection and also to attenuate self-tolerance in autoimmune diseases [81-85]. MDSC cross talk with macrophages, DCs and other effector immune cells has been reviewed previously $[6,52,86]$, whereas their interaction with $\mathrm{T}_{\text {reg }}$ cells is less-well appreciated.

MDSCs and $\mathrm{CD} 4^{+} \mathrm{CD} 25^{+} \mathrm{FoxP}^{+} \mathrm{T}_{\text {reg }}$ cells represent two major classes of suppressive cells that play crucial roles in the establishment and maintenance of peripheral 
immune tolerance. Both MDSCs and $\mathrm{T}_{\text {reg }}$ cells have been reported to synergistically inhibit immune effector cell function and maintain tumor tolerance in tumor-bearing mice $[87,88]$. One study has shown that primarily GMDSCs can inhibit natural $\mathrm{T}_{\text {reg }}$ cell proliferation and prevent inducible $\mathrm{T}_{\text {reg }}$ cell differentiation from naïve $\mathrm{CD} 4^{+} \mathrm{T}$ cells. However, this study did not exclude the possibility that M-MDSCs might prime $\mathrm{T}_{\text {reg }}$ cell development [89].

In cancer, the tumor microenvironment can further induce MDSCs to differentiate into tumor-associated macrophages, which appear endowed with more suppressive capability and which can induce IL-10 [85], TGF- $\beta$, PE2 [89] and CC-chemokine ligand 22 (CCL22) [90] production to attract and promote $\mathrm{T}_{\text {reg }}$ cell development and attenuate antitumor immunity rather than directly inhibiting innate immunity via PD-L1 [91] or ARG1 [92]. We speculate that, during the early stages of inflammation as observed in acute sepsis, $\mathrm{T}_{\text {reg }}$ cells may partially function to inhibit the initial excessive inflammatory reaction before adequate numbers of MDSCs are generated. During early inflammation, IMCs exhibit the same surface markers as MDSCs but are not immunosuppressive. We suspect that these MDSC-like cells may exert normal immune properties for antimicrobial effects at this stage. Later on, with infection persistence, these IMCs aberrantly differentiate into MDSCs, exerting their immunosuppressive functions at a later stage.

Here, we describe two distinct populations and suppressive mechanisms for both MDSCs and $\mathrm{T}_{\text {reg }}$ cells: the inherent natural population and the acquired inducible population. Because MDSCs are derived from aberrant myelopoiesis under pathologic conditions, their suppressive ability is not an inherent trait, as is observed in natural $\mathrm{T}_{\text {reg }}$ cells, but rather induced by pathogenic products and inflammatory cytokines so as to induce $\mathrm{T}_{\text {reg }}$ cells. MDSCs communicate with and orchestrate aspects of the human immune defense system, balancing $\mathrm{T}_{\text {reg }}$ and effector $\mathrm{T}$ cells, whereby persistent pathogens strengthen their immunosuppressive activities. In comparison, natural $\mathrm{T}_{\text {reg }}$ cells are part of the inherent host defense system, exerting more comprehensive and long-lasting surveillance for the host over self-immune reactions. The suppressive power of $\mathrm{T}_{\text {reg }}$ cells against host immune responses may serve as an additional mechanism for promoting MDSC expansion and activation under pathological conditions. If we deem ARG1 [92], $\mathrm{H}_{2} \mathrm{O}_{2}$ and nitrosylation of effector immune cell receptors [93-95] as direct and primary weapons used by MDSCs against effector immune cells $[52,96]$, then IL-10 [85], TGF- $\beta$ [89] and ROS [97] are the indirect or secondary mediators that expand the
MDSC immunosuppressive cascade, in conjunction with inducible $\mathrm{T}_{\text {reg }}$ cell development. Through induction and interaction of MDSCs and $\mathrm{T}_{\text {reg }}$ cells [88], persistent pathogens (e.g. HIV/HCV) can suppress antigen-specific [19, $94,98]$ or nonspecific $[34,99,100]$ effector immune cells for their survival benefit, leading to immune tolerance characterized by a relatively benign immune-mediated injury, but at the expense of chronic infection $[101,102]$.

\section{Conclusion}

The discovery of MDSCs and characterization of their immunosuppressive functions have shed new light on the pathogenesis of many inflammatory diseases. This review has focused discussion on MDSCs in infection-driven inflammation, comparing their properties to tumor-driven MDSCs. Notably, MDSCs may serve as a double-edged sword during the early and late stages of infection and inflammation, from boosting innate immunity in early stages to attenuating the immune system through promoting immunosuppression in late stages of infection. How MDSC phenotypes and functional activities shift along with the host early proinflammatory to late anti-inflammatory phase and how they cross-interact with $\mathrm{T}_{\text {reg }}$ cells require further investigations. Although some suggest that increasing MDSCs during infection may help limit undesirable inflammatory damage, and boosting MDSC proliferation during an uncontrolled inflammatory response may reduce undesirable inflammation [103], MDSC expansion and activity are not an inherent homeostatic mechanism which the immune system can utilize to return to a noninflammatory state. MDSCs are induced under pathologic conditions and may help balance the immune threshold and induce a weak host response to pathogens. The precise mechanisms of how factors derived from the invading pathogens or inflammatory mediators drive the expansion and activation of MDSCs and their trafficking to the sites of tumor or infection to exert suppressive functions are still under investigation. Taken together, elucidating all the biological and functional aspects of MDSCs will contribute to our understanding of the immunobiology of infection and inflammation and eventually help develop prophylactic or therapeutic approaches for inflammatory diseases.

\section{Acknowledgements}

This work was supported by an NIH NIDDK grant to ZQY/ JPM (R01DK093526) and an NIH NIAID grant to ZQY/JPM (R01AI114748). 


\section{References}

1 Buessow SC, Paul RD, Lopez DM: Influence of mammary tumor progression on phenotype and function of spleen and in situ lymphocytes in mice. J Natl Cancer Inst 1984;73: 249-255.

-2 Young MR, Newby M, Wepsic HT: Hematopoiesis and suppressor bone marrow cells in mice bearing large metastatic Lewis lung carcinoma tumors. Cancer Res 1987;47:100-105.

-3 Seung LP, Rowley DA, Dubey P, Schreiber H: Synergy between T-cell immunity and inhibition of paracrine stimulation causes tumor rejection. Proc Natl Acad Sci U S A 1995;92: 6254-6258.

4 Murphey ED, Lin CY, McGuire RW, ToliverKinsky T, Herndon DN, Sherwood ER: Diminished bacterial clearance is associated with decreased IL-12 and interferon-gamma production but a sustained proinflammatory response in a murine model of postseptic immunosuppression. Shock 2004;21:415-425.

5 Delano MJ, Scumpia PO, Weinstein JS, Coco D, Nagaraj S, Kelly-Scumpia KM, O’Malley KA, Wynn JL, Antonenko S, Al-Quran SZ, Swan R, Chung CS, Atkinson MA, Ramphal R, Gabrilovich DI, Reeves WH, Ayala A, Phillips J, Laface D, Heyworth PG, Clare-Salzler M, Moldawer LL: MyD88-dependent expansion of an immature GR-1(+)CD11b(+) population induces $\mathrm{T}$ cell suppression and Th2 polarization in sepsis. J Exp Med 2007;204 1463-1474.

6 Ostrand-Rosenberg S, Sinha P: Myeloid-derived suppressor cells: linking inflammation and cancer. J Immunol 2009;182:4499-4506.

7 Gabrilovich DI, Nagaraj S: Myeloid-derived suppressor cells as regulators of the immune system. Nat Rev Immunol 2009;9:162-174.

-8 Bunt SK, Sinha P, Clements VK, Leips J, Ostrand-Rosenberg S: Inflammation induces myeloid-derived suppressor cells that facilitate tumor progression. J Immunol 2006; 176: 284-290.

-9 Pande K, Ueda R, Machemer T, Sathe M, Tsai V, Brin E, Delano MJ, Van Rooijen N, McClanahan TK, Talmadge JE, Moldawer LL, Phillips JH, LaFace DM: Cancer-induced expansion and activation of CD11b+Gr-1+ cells predispose mice to adenoviral-triggered anaphylactoid-type reactions. Mol Ther 2009;17: 508-515.

10 Mantovani A, Sozzani S, Locati M, Allavena P, Sica A: Macrophage polarization: tumorassociated macrophages as a paradigm for polarized M2 mononuclear phagocytes. Trends Immunol 2002;23:549-555.

11 Vollbrecht T, Stirner R, Tufman A, Roider J, Huber RM, Bogner JR, Lechner A, Bourquin C, Draenert R: Chronic progressive HIV-1 infection is associated with elevated levels of myeloid-derived suppressor cells. AIDS 2012; 26:F31-F37.

-12 Tacke RS, Lee HC, Goh C, Courtney J, Polyak SJ, Rosen HR, Hahn YS: Myeloid suppressor cells induced by hepatitis $\mathrm{C}$ virus suppress T- cell responses through the production of reactive oxygen species. Hepatology 2012;55:343353.

13 Brudecki L, Ferguson DA, McCall CE, El Gazzar M: Myeloid-derived suppressor cells evolve during sepsis and can enhance or attenuate the systemic inflammatory response. Infect Immun 2012;80:2026-2034.

14 Yang WC, Ma G, Chen SH, Pan PY: Polarization and reprogramming of myeloid-derived suppressor cells. J Mol Cell Biol 2013;5:207209.

15 Cuenca AG, Delano MJ, Kelly-Scumpia KM, Moreno C, Scumpia PO, Laface DM, Heyworth PG, Efron PA, Moldawer LL: A paradoxical role for myeloid-derived suppressor cells in sepsis and trauma. Mol Med 2011;17: 281-292.

-16 Norris BA, Uebelhoer LS, Nakaya HI, Price AA, Grakoui A, Pulendran B: Chronic but not acute virus infection induces sustained expansion of myeloid suppressor cell numbers that inhibit viral-specific $\mathrm{T}$ cell immunity. Immunity 2013;38:309-321.

17 Zhao F, Obermann S, von Wasielewski R, Haile L, Manns MP, Korangy F, Greten TF Increase in frequency of myeloid-derived suppressor cells in mice with spontaneous pancreatic carcinoma. Immunology 2009; 128:141-149.

18 Ilkovitch D, Lopez DM: The liver is a site for tumor-induced myeloid-derived suppressor cell accumulation and immunosuppression. Cancer Res 2009;69:5514-5521.

19 Ezernitchi AV, Vaknin I, Cohen-Daniel L, Levy O, Manaster E, Halabi A, Pikarsky E, Shapira L, Baniyash M: TCR zeta downregulation under chronic inflammation is mediated by myeloid suppressor cells differentially distributed between various lymphatic organs. J Immunol 2006;177: 4763-4772.

20 Greifenberg V, Ribechini E, Rossner S, Lutz MB: Myeloid-derived suppressor cell activation by combined LPS and IFN-gamma treatment impairs DC development. Eur J Immunol 2009;39:2865-2876.

21 Sinha P, Clements VK, Ostrand-Rosenberg S: Reduction of myeloid-derived suppressor cells and induction of M1 macrophages facilitate the rejection of established metastatic disease. J Immunol 2005;174:636-645.

22 Bronte V: Myeloid-derived suppressor cells in inflammation: uncovering cell subsets with enhanced immunosuppressive functions. Eur J Immunol 2009;39:2670-2672.

23 Movahedi K, Guilliams M, Van den Bossche J, Van den Bergh R, Gysemans C, Beschin A, De Baetselier P, Van Ginderachter JA: Identification of discrete tumor-induced myeloidderived suppressor cell subpopulations with distinct $\mathrm{T}$ cell-suppressive activity. Blood 2008;111:4233-4244.

24 Kusmartsev S, Nefedova Y, Yoder D, Gabrilovich DI: Antigen-specific inhibition of
CD8+ T cell response by immature myeloid cells in cancer is mediated by reactive oxygen species. J Immunol 2004;172:989-999.

25 Yang R, Cai Z, Zhang Y, Yutzy WH 4th, Roby KF, Roden RB: CD80 in immune suppression by mouse ovarian carcinoma-associated $\mathrm{Gr}$ 1+CD11b+ myeloid cells. Cancer Res 2006; 66:6807-6815.

26 Brys L, Beschin A, Raes G, Ghassabeh GH, Noel W, Brandt J, Brombacher F, De Baetselier P: Reactive oxygen species and 12/15-lipoxygenase contribute to the antiproliferative capacity of alternatively activated myeloid cells elicited during helminth infection. J Immunol 2005;174:6095-6104.

27 Zhou R, He PL, Ren YX, Wang WH, Zhou RY, Wan H, Ono S, Fujiwara H, Zuo JP: Myeloid suppressor cell-associated immune dysfunction in CSA1M fibrosarcoma tumor-bearing mice. Cancer Sci 2007;98:882889 .

28 Kong YY, Fuchsberger M, Xiang SD, Apostolopoulos V, Plebanski M: Myeloid derived suppressor cells and their role in diseases. Curr Med Chem 2013;20:1437-1444.

29 Rossner S, Voigtlander C, Wiethe C, Hanig J, Seifarth C, Lutz MB: Myeloid dendritic cell precursors generated from bone marrow suppress $\mathrm{T}$ cell responses via cell contact and nitric oxide production in vitro. Eur J Immunol 2005;35:3533-3544.

30 Li Q, Pan PY, Gu P, Xu D, Chen SH: Role of immature myeloid Gr-1+ cells in the development of antitumor immunity. Cancer Res 2004;64:1130-1139.

31 Narita Y, Wakita D, Ohkur T, Chamoto K, Nishimura T: Potential differentiation of tumor bearing mouse $\mathrm{CD} 11 \mathrm{~b}+\mathrm{Gr}-1+$ immature myeloid cells into both suppressor macrophages and immunostimulatory dendritic cells. Biomed Res 2009;30:7-15.

-32 Danna EA, Sinha P, Gilbert M, Clements VK, Pulaski BA, Ostrand-Rosenberg S: Surgical removal of primary tumor reverses tumorinduced immunosuppression despite the presence of metastatic disease. Cancer Res 2004;64:2205-2211.

33 Serafini P, Carbley R, Noonan KA, Tan G, Bronte V, Borrello I: High-dose granulocyte-macrophage colony-stimulating factor-producing vaccines impair the immune response through the recruitment of myeloid suppressor cells. Cancer Res 2004;64: 6337-6343.

34 Hosoi A, Matsushita H, Shimizu K, Fujii S, Ueha S, Abe J, Kurachi M, Maekawa R, Matsushima K, Kakimi K: Adoptive cytotoxic T lymphocyte therapy triggers a counter-regulatory immunosuppressive mechanism via recruitment of myeloid-derived suppressor cells. Int J Cancer 2014;134:1810-1822.

35 Wesche DE, Lomas-Neira JL, Perl M, Chung CS, Ayala A: Leukocyte apoptosis and its significance in sepsis and shock. J Leukoc Biol 2005;78:325-337. 
36 Wysocka M, Robertson S, Riemann H, Caamano J, Hunter C, Mackiewicz A, Montaner LJ, Trinchieri G, Karp CL: IL-12 suppression during experimental endotoxin tolerance: dendritic cell loss and macrophage hyporesponsiveness. J Immunol 2001;166:7504-7513.

- 37 Ling V, Luxenberg D, Wang J, Nickbarg E, Leenen PJ, Neben S, Kobayashi M: Structural identification of the hematopoietic progenitor antigen ER-MP12 as the vascular endothelial adhesion molecule PECAM-1 (CD31). Eur J Immunol 1997;27:509-514.

38 Hotchkiss RS, Karl IE: The pathophysiology and treatment of sepsis. N Engl J Med 2003; 348:138-150.

-39 Oberholzer A, Oberholzer C, Moldawer LL: Sepsis syndromes: understanding the role of innate and acquired immunity. Shock 2001; 16:83-96.

-40 Umemura N, Saio M, Suwa T, Kitoh Y, Bai J, Nonaka K, Ouyang GF, Okada M, Balazs M, Adany R, Shibata T, Takami T: Tumor-infiltrating myeloid-derived suppressor cells are pleiotropic-inflamed monocytes/macrophages that bear M1- and M2-type characteristics. J Leukoc Biol 2008;83:1136-1144.

41 Cavaillon JM, Adib-Conquy M: Bench-tobedside review: endotoxin tolerance as a model of leukocyte reprogramming in sepsis. Crit Care 2006;10:233.

-42 Rossato M, Curtale G, Tamassia N, Castellucci M, Mori L, Gasperini S, Mariotti B, De Luca M, Mirolo M, Cassatella MA, Locati M, Bazzoni F: IL-10-induced microRNA-187 negatively regulates TNF-alpha, IL-6, and IL$12 \mathrm{p} 40$ production in TLR4-stimulated monocytes. Proc Natl Acad Sci U S A 2012;109: E3101-E3110.

43 Biswas SK, Lopez-Collazo E: Endotoxin tolerance: new mechanisms, molecules and clinical significance. Trends Immunol 2009;30: 475-487.

-44 Xiao W, Mindrinos MN, Seok J, Cuschieri J, Cuenca AG, Gao H, Hayden DL, Hennessy L, Moore EE, Minei JP, Bankey PE, Johnson JL, Sperry J, Nathens AB, Billiar TR, West MA, Brownstein $\mathrm{BH}$, Mason $\mathrm{PH}$, Baker HV, Finnerty CC, Jeschke MG, Lopez MC, Klein MB, Gamelli RL, Gibran NS, Arnoldo B, Xu W, Zhang Y, Calvano SE, McDonald-Smith GP, Schoenfeld DA, Storey JD, Cobb JP, Warren HS, Moldawer LL, Herndon DN, Lowry SF, Maier RV, Davis RW, Tompkins RG; Inflammation and Host Response to Injury Large-Scale Collaborative Research Program: A genomic storm in critically injured humans. J Exp Med 2011;208:2581-2590.

45 Filipazzi P, Valenti R, Huber V, Pilla L, Canese P, Iero M, Castelli C, Mariani L, Parmiani G, Rivoltini L: Identification of a new subset of myeloid suppressor cells in peripheral blood of melanoma patients with modulation by a granulocyte-macrophage colonystimulation factor-based antitumor vaccine. J Clin Oncol 2007;25:2546-2553.

46 Mirza N, Fishman M, Fricke I, Dunn M, Neuger AM, Frost TJ, Lush RM, Antonia S,
Gabrilovich DI: All-trans-retinoic acid improves differentiation of myeloid cells and immune response in cancer patients. Cancer Res 2006;66:9299-9307.

47 Zea AH, Rodriguez PC, Atkins MB, Hernandez C, Signoretti S, Zabaleta J, McDermott D, Quiceno D, Youmans A, O’Neill A, Mier J, Ochoa AC: Arginase-producing myeloid suppressor cells in renal cell carcinoma patients: a mechanism of tumor evasion. Cancer Res 2005;65:3044-3048.

- 48 Srivastava MK, Bosch JJ, Thompson JA, Ksander BR, Edelman MJ, Ostrand-Rosenberg S: Lung cancer patients' CD4(+) T cells are activated in vitro by MHC II cell-based vaccines despite the presence of myeloid-derived suppressor cells. Cancer Immunol Immunother 2008;57:1493-1504.

49 Hoechst B, Ormandy LA, Ballmaier M, Lehner F, Kruger C, Manns MP, Greten TF, Korangy F: A new population of myeloid-derived suppressor cells in hepatocellular carcinoma patients induces CD4(+)CD25(+) Foxp3(+) T cells. Gastroenterology 2008; 135: 234-243.

50 Liu CY, Wang YM, Wang CL, Feng PH, Ko HW, Liu YH, Wu YC, Chu Y, Chung FT, Kuo $\mathrm{CH}$, Lee KY, Lin SM, Lin HC, Wang CH, Yu CT, Kuo HP: Population alterations of L-arginase- and inducible nitric oxide synthase-expressed CD11b+/CD14(-)/CD15+/CD33+ myeloid-derived suppressor cells and CD8+ T lymphocytes in patients with advanced-stage non-small cell lung cancer. J Cancer Res Clin Oncol 2010;136:35-45.

51 Poschke I, Mougiakakos D, Hansson J, Masucci GV, Kiessling R: Immature immunosuppressive CD14+HLA-DR-/low cells in melanoma patients are Stat3hi and overexpress CD80, CD83, and DC-sign. Cancer Res 2010;70:4335-4345.

-52 Gabrilovich DI, Ostrand-Rosenberg S, Bronte $\mathrm{V}$ : Coordinated regulation of myeloid cells by tumours. Nat Rev Immunol 2012;12:253-268.

53 Basso D, Fogar P, lebani MP: The S100A8/A9 complex reduces CTLA4 expression by immature myeloid cells: implications for pancreatic cancer-driven immunosuppression. Oncoimmunology 2013;2:e24441.

54 Schmielau J, Finn OJ: Activated granulocytes and granulocyte-derived hydrogen peroxide are the underlying mechanism of suppression of T-cell function in advanced cancer patients. Cancer Res 2001;61:4756-4760.

55 Youn JI, Nagaraj S, Collazo M, Gabrilovich DI: Subsets of myeloid-derived suppressor cells in tumor-bearing mice. J Immunol 2008; 181:5791-5802.

56 Rodriguez PC, Ernstoff MS, Hernandez C, Atkins M, Zabaleta J, Sierra R, Ochoa AC: Arginase I-producing myeloid-derived suppressor cells in renal cell carcinoma are a subpopulation of activated granulocytes. Cancer Res 2009;69:1553-1560.

-57 Waight JD, Hu Q, Miller A, Liu S, Abrams SI: Tumor-derived G-CSF facilitates neoplastic growth through a granulocytic myeloid-de- rived suppressor cell-dependent mechanism. PLoS One 2011;6:e27690.

58 Dolcetti L, Peranzoni E, Ugel S, Marigo I, Fernandez Gomez A, Mesa C, Geilich M, Winkels G, Traggiai E, Casati A, Grassi F, Bronte V: Hierarchy of immunosuppressive strength among myeloid-derived suppressor cell subsets is determined by GM-CSF. Eur J Immunol 2010;40:22-35.

59 Lindau D, Gielen P, Kroesen M, Wesseling P, Adema GJ: The immunosuppressive tumour network: myeloid-derived suppressor cells, regulatory $\mathrm{T}$ cells and natural killer $\mathrm{T}$ cells. Immunology 2013;138:105-115.

60 Dietlin TA, Hofman FM, Lund BT, Gilmore W, Stohlman SA, van der Veen RC: Mycobacteria-induced $\mathrm{Gr}-1+$ subsets from distinct myeloid lineages have opposite effects on T cell expansion. J Leukoc Biol 2007;81:1205-1212.

61 Zhu B, Bando Y, Xiao S, Yang K, Anderson AC, Kuchroo VK, Khoury SJ: CD11b+Ly6C(hi) suppressive monocytes in experimental autoimmune encephalomyelitis. J Immunol 2007;179:5228-5237.

62 Makarenkova VP, Bansal V, Matta BM, Perez LA, Ochoa JB: CD11b+/Gr-1+ myeloid suppressor cells cause $T$ cell dysfunction after traumatic stress. J Immunol 2006; 176:2085-2094.

63 Tamayo E, Gomez E, Bustamante J, GomezHerreras JI, Fonteriz R, Bobillo F, BermejoMartin JF, Castrodeza J, Heredia M, Fierro I, Alvarez FJ: Evolution of neutrophil apoptosis in septic shock survivors and nonsurvivors. J Crit Care 2012;27:415.e1-e11.

-64 Drifte G, Dunn-Siegrist I, Tissieres P, Pugin J: Innate immune functions of immature neutrophils in patients with sepsis and severe systemic inflammatory response syndrome. Crit Care Med 2013;41:820-832.

65 Alves-Filho JC, Spiller F, Cunha FQ: Neutrophil paralysis in sepsis. Shock 2010; 34(suppl 1):15-21.

66 Kovach MA, Standiford TJ: The function of neutrophils in sepsis. Curr Opin Infect Dis 2012;25:321-327.

-67 Kusmartsev S, Gabrilovich DI: STAT1 signaling regulates tumor-associated macrophagemediated T cell deletion. J Immunol 2005; 174:4880-4891.

68 Muller AJ, Prendergast GC: Indoleamine 2,3-dioxygenase in immune suppression and cancer. Curr Cancer Drug Targets 2007;7:3140.

69 Marx J: Cancer immunology. Cancer's bulwark against immune attack: MDS cells. Science 2008;319:154-156.

70 Srivastava MK, Dubinett S, Sharma S: Targeting MDSCs enhance therapeutic vaccination responses against lung cancer. Oncoimmunology 2012;1:1650-1651.

71 Sander LE, Sackett SD, Dierssen U, Beraza N, Linke RP, Muller M, Blander JM, Tacke F, Trautwein C: Hepatic acute-phase proteins control innate immune responses during infection by promoting myeloid-derived suppressor cell function. J Exp Med 2010;207: 1453-1464. 
72 Arocena AR, Onofrio LI, Pellegrini AV, Carrera Silva AE, Paroli A, Cano RC, Aoki MP, Gea S: Myeloid-derived suppressor cells are key players in the resolution of inflammation during a model of acute infection. Eur J Immunol 2014;44:184-194.

-73 Hotchkiss RS, Monneret G, Payen D: Sepsisinduced immunosuppression: from cellular dysfunctions to immunotherapy. Nat Rev Immunol 2013;13:862-874.

74 Haverkamp JM, Crist SA, Elzey BD, Cimen C, Ratliff TL: In vivo suppressive function of myeloid-derived suppressor cells is limited to the inflammatory site. Eur J Immunol 2011;41: 749-759.

75 Macatangay B, Roper J, Borowski L, Whiteside TL, Rinaldo CR: Levels of cellular immune activation and myeloid-derived suppressor cells are elevated after administration of an HIV-dendritic cell therapeutic vaccine. Conference on Retroviruses and Opportunistic Infections, Boston, 2011.

-76 Macatangay BJ, Szajnik ME, Whiteside TL, Riddler SA, Rinaldo CR: Regulatory T cell suppression of Gag-specific CD8 T cell polyfunctional response after therapeutic vaccination of HIV-1-infected patients on ART. PLoS One 2010;5:e9852.

-77 Shan L, Deng K, Shroff NS, Durand CM, Rabi SA, Yang HC, Zhang H, Margolick JB, Blankson JN, Siliciano RF: Stimulation of HIV1-specific cytolytic $\mathrm{T}$ lymphocytes facilitates elimination of latent viral reservoir after virus reactivation. Immunity 2012;36:491-501.

-78 Macatangay BJ, Landay AL, Rinaldo CR: MDSC: a new player in HIV immunopathogenesis. AIDS 2012;26:1567-1569.

-79 Qin A, Cai W, Pan T, Wu K, Yang Q, Wang N, Liu Y, Yan D, Hu F, Guo P, Chen X, Chen L, Zhang H, Tang X, Zhou J: Expansion of monocytic myeloid-derived suppressor cells dampens $\mathrm{T}$ cell function in HIV-1-seropositive individuals. J Virol 2013;87:1477-1490.

-80 Garg A, Spector SA:HIV type 1 gp120-induced expansion of myeloid derived suppressor cells is dependent on interleukin 6 and suppresses immunity. J Infect Dis 2014;209:441-451.

-81 Bluestone JA, Thomson AW, Shevach EM, Weiner HL: What does the future hold for cell-based tolerogenic therapy? Nat Rev Immunol 2007;7:650-654.

82 Dilek N, Poirier N, Usal C, Martinet B, Blancho G, Vanhove B: Control of transplant tolerance and intragraft regulatory $\mathrm{T}$ cell localization by myeloid-derived suppressor cells and CCL5. J Immunol 2012;188:4209-4216.

83 Carbone F, De Rosa V, Carrieri PB, Montella S, Bruzzese D, Porcellini A, Procaccini C, La Cava A, Matarese G: Regulatory T cell proliferative potential is impaired in human autoimmune disease. Nat Med 2014;20:69-74.

84 Luan Y, Mosheir E, Menon MC, Wilson D, Woytovich C, Ochando J, Murphy B: Monocytic myeloid-derived suppressor cells accumulate in renal transplant patients and mediate CD4(+) Foxp3(+) Treg expansion. Am J Transplant 2013;13:3123-3131.
85 Murai M, Turovskaya O, Kim G, Madan R, Karp CL, Cheroutre H, Kronenberg M: Interleukin 10 acts on regulatory $\mathrm{T}$ cells to maintain expression of the transcription factor Foxp3 and suppressive function in mice with colitis. Nat Immunol 2009;10:1178-1184

86 Ostrand-Rosenberg S, Sinha P, Beury DW, Clements VK: Cross-talk between myeloidderived suppressor cells (MDSC), macrophages, and dendritic cells enhances tumorinduced immune suppression. Semin Cancer Biol 2012;22:275-281.

87 Huang B, Pan PY, Li Q, Sato Al, Levy DE, Bromberg J, Divino CM, Chen SH: Gr1+CD115+ immature myeloid suppressor cells mediate the development of tumor-induced $\mathrm{T}$ regulatory cells and T-cell anergy in tumor-bearing host. Cancer Res 2006;66: 1123-1131.

-88 Pan PY, Ma G, Weber KJ, Ozao-Choy J, Wang G, Yin B, Divino CM, Chen SH: Immune stimulatory receptor CD40 is required for $\mathrm{T}$ cell suppression and $\mathrm{T}$ regulatory cell activation mediated by myeloid-derived suppressor cells in cancer. Cancer Res 2010;70:99-108.

89 Torroella-Kouri M, Silvera R, Rodriguez D, Caso R, Shatry A, Opiela S, Ilkovitch D, Schwendener RA, Iragavarapu-Charyulu V, Cardentey Y, Strbo N, Lopez DM: Identification of a subpopulation of macrophages in mammary tumor-bearing mice that are neither M1 nor M2 and are less differentiated. Cancer Res 2009;69:4800-4809.

-90 Curiel TJ, Coukos G, Zou L, Alvarez X, Cheng P, Mottram P, Evdemon-Hogan M, ConejoGarcia JR, Zhang L, Burow M, Zhu Y, Wei S, Kryczek I, Daniel B, Gordon A, Myers L, Lackner A, Disis ML, Knutson KL, Chen L, Zou W: Specific recruitment of regulatory $\mathrm{T}$ cells in ovarian carcinoma fosters immune privilege and predicts reduced survival. Nat Med 2004;10:942-949.

91 Kuang DM, Zhao Q, Peng C, Xu J, Zhang JP, Wu C, Zheng L: Activated monocytes in peritumoral stroma of hepatocellular carcinoma foster immune privilege and disease progression through PD-L1. J Exp Med 2009;206: 1327-1337.

92 Rodriguez PC, Quiceno DG, Zabaleta J, Ortiz B, Zea AH, Piazuelo MB, Delgado A, Correa P, Brayer J, Sotomayor EM, Antonia S, Ochoa JB, Ochoa AC: Arginase I production in the tumor microenvironment by mature myeloid cells inhibits T-cell receptor expression and antigen-specific $\mathrm{T}$-cell responses. Cancer Res 2004;64:5839-5849.

$93 \mathrm{Lu} \mathrm{T}$, Ramakrishnan R, Altiok S, Youn JI, Cheng P, Celis E, Pisarev V, Sherman S, Sporn MB, Gabrilovich D: Tumor-infiltrating myeloid cells induce tumor cell resistance to cytotoxic T cells in mice. J Clin Invest 2011;121: 4015-4029.
94 Nagaraj S, Gupta K, Pisarev V, Kinarsky L, Sherman S, Kang L, Herber DL, Schneck J, Gabrilovich DI: Altered recognition of antigen is a mechanism of CD8+ T cell tolerance in cancer. Nat Med 2007;13:828-835.

$\checkmark 95$ Molon B, Ugel S, Del Pozzo F, Soldani C, Zilio S, Avella D, De Palma A, Mauri P, Monegal A, Rescigno M, Savino B, Colombo P, Jonjic N, Pecanic S, Lazzarato L, Fruttero R, Gasco A, Bronte V, Viola A: Chemokine nitration prevents intratumoral infiltration of antigen-specific T cells. J Exp Med 2011; 208:1949-1962.

96 Sinha P, Clements VK, Bunt SK, Albelda SM, Ostrand-Rosenberg S: Cross-talk between myeloid-derived suppressor cells and macrophages subverts tumor immunity toward a type 2 response. J Immunol 2007;179: 977-983.

$\checkmark 97$ Kraaij MD, Savage ND, van der Kooij SW, Koekkoek K, Wang J, van den Berg JM, Ottenhoff TH, Kuijpers TW, Holmdahl R, van Kooten C, Gelderman KA: Induction of regulatory $\mathrm{T}$ cells by macrophages is dependent on production of reactive oxygen species. Proc Natl Acad Sci U S A 2010;107:17686-17691.

-98 Watanabe S, Deguchi K, Zheng R, Tamai H, Wang LX, Cohen PA, Shu S: Tumor-induced $\mathrm{CD} 1 \mathrm{~b}+\mathrm{Gr}-1+$ myeloid cells suppress T cell sensitization in tumor-draining lymph nodes. J Immunol 2008;181:3291-3300.

$\$ 99$ Corzo CA, Condamine T, Lu L, Cotter MJ, Youn JI, Cheng P, Cho HI, Celis E, Quiceno DG, Padhya T, McCaffrey TV, McCaffrey JC, Gabrilovich DI: HIF-1alpha regulates function and differentiation of myeloid-derived suppressor cells in the tumor microenvironment. J Exp Med 2010;207:2439-2453.

100 Nagaraj S, Nelson A, Youn JI, Cheng P, Quiceno D, Gabrilovich DI: Antigen-specific CD4(+) T cells regulate function of myeloidderived suppressor cells in cancer via retrograde MHC class II signaling. Cancer Res 2012;72:928-938.

101 Verma C, Eremin JM, Robins A, Bennett AJ, Cowley GP, El-Sheemy MA, Jibril JA, Eremin O: Abnormal T regulatory cells (Tregs: FOXP3+, CTLA-4+), myeloid-derived suppressor cells (MDSCs: monocytic, granulocytic) and polarised $\mathrm{T}$ helper cell profiles (Th1, Th2, Th17) in women with large and locally advanced breast cancers undergoing neoadjuvant chemotherapy (NAC) and surgery: failure of abolition of abnormal treg profile with treatment and correlation of treg levels with pathological response to NAC. J Transl Med 2013;11:16.

102 Adeegbe D, Serafini P, Bronte V, Zoso A, Ricordi $\mathrm{C}$, Inverardi L: In vivo induction of myeloid suppressor cells and $\mathrm{CD} 4(+)$ Foxp3(+) T regulatory cells prolongs skin allograft survival in mice. Cell Transplant 2011;20:941-954.

103 Goh C, Narayanan S, Hahn YS: Myeloid-derived suppressor cells: the dark knight or the joker in viral infections? Immunol Rev 2013; 255:210-221. 